Citation: Boudjbir, H., Mahri, Z.L., Elayoubi, K.S.E., "A Thermal Comfort Evaluation Using a Statistical Analysis of Interior Temperature for a Building Located in Constantine, Algeria". Journal of Engineering Technology and Applied Sciences 5 (1) 2020 : 13-18.

\title{
A THERMAL COMFORT EVALUATION USING A STATISTICAL ANALYSIS OF INTERIOR TEMPERATURE FOR A BUILDING LOCATED IN CONSTANTINE, ALGERIA
}

\author{
Hind Boudjbir ${ }^{\mathrm{a}}$, Zine Labidine Mahria* (D), Krada Salah Eddine Elayoubi ${ }^{\mathrm{b}}$ \\ ${ }^{a}$ Laboratoire de génie climatique Université des frères Mentouri, Constantine, Algeria \\ zlmahri@hotmail.com (*corresponding author) \\ ${ }^{b}$ Université Salah Boubnider, Constantine, Algeria
}

\begin{abstract}
The objective of this study is to analyze the thermal behavior of a residential building with an aim of estimating thermal comfort in this building for a case of passive air conditioning. Passive air conditioning can play a major role in promoting energy efficiency in the building sector [1]. Considering that this sector is one of the main targets of the improvement of energy efficiency, since it represents today more than one-third of the worldwide consumption of energy and an equivalent amount of its associated emissions [2]. In Algeria, this sector has the highest energy consumption. Its consumption represents more than $42 \%$ of the total final consumption [3].
\end{abstract}

Keywords: Thermal engineering, thermal confort, numerical simulation, TRNSYS software

\section{Introduction.}

In this work a numerical simulation using TRNSYS software was carried out, in order to determine the annual distribution of temperatures inside this building. This thermal simulation allows us to estimate the hourly value of the temperature inside each room for a chosen location.

The objective of this work is to investigate the thermal comfort in this building for a case of a passive air conditioning, while other studies [4] [5], aim to evaluate energy consumption for active air conditioning.

To carry out this simulation a detailed description of the building characteristics is given with precision, in addition the rate of occupation of different rooms and the timetable relative to 
the use of lighting and other appliances are provided [6]. The site of the selected building is the town of Constantine located east of Algeria.

In order to perform a statistical analysis of the results obtained by the TRNSYS software, a computer program has been developed in order to process these results. This processing made possible the calculation of the statistical distribution of temperatures throughout the year, based on the annual distribution of the building's interior temperatures.

In this study two statistical distributions were determined namely the probability density as well as the cumulative probability of the interior temperature of the building. The probability density of the temperature gives the probability of annual occurrence of each temperature value, while the cumulative probability gives the probability that the temperature would be less than a given value during the annual period. The distribution of the cumulative probability of interior temperatures calculated for the two extreme seasons, namely winter and summer, made possible the analysis and the estimation of the duration of thermal comfort for passive air conditioning.

\section{A numerical simulation using TRNSYS software.}

In this simulation a detailed description of the building used is given with precision, such as the details concerning the building envelope (type of wall, type of window, orientation, solar protection etc ...).

Moreover a schedule (scenario) of occupation of different rooms is provided with the level of activity of each occupant. In addition, a schedule describing the use of lighting and that of the various appliances, which contribute to the internal heat gains, is elaborated.

\subsection{The description of the building plan.}

- The following plan shows the details of the building used.

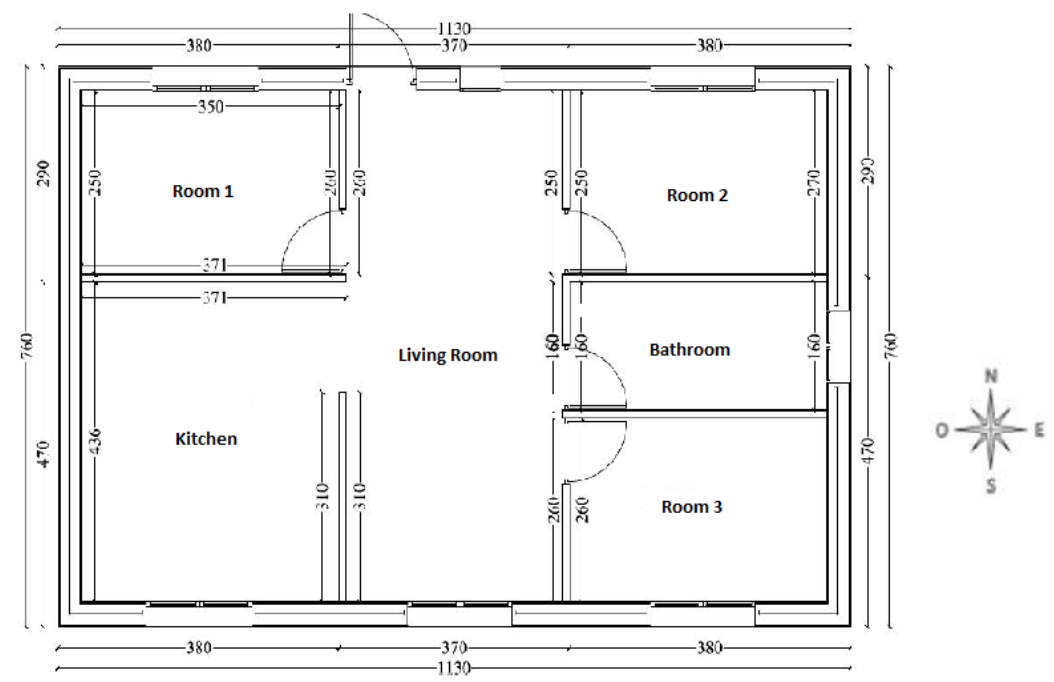

Figure 1. Building plan 
- The construction material used for this building:

- The building envelope is built with double walls.

- The external walls are made with brick having a thickness of $15 \mathrm{~cm}$.

- All the internal walls are made with brick having a thickness of $10 \mathrm{~cm}$.

- For thermal insulation, $5 \mathrm{~cm}$ thick of polystyrene sheets are used.

- Type of windows used:

- Double glazed windows.

2.2 The geographical and meteorological characteristics of the building location.

The site of the selected building is the town of Constantine located east of Algeria and having the geographical and weather characteristics as follow:

- $\quad$ Latitude $36.17^{\circ}$ north

- $\quad$ Longitude $6.37^{\circ}$ east

- $\quad$ Altitude is of $694 \mathrm{~m}$

- $\quad$ Located in climatic zone B

The weather data of this site are ensured by a weather file provided by the software.

\subsection{The simulation results.}

This thermal simulation is carried out using the TRNSYS software, its results are presented in the following parts:

- In the case of active air conditioning, if the heating and the air conditioning are in use (the equipment are activated in the software options), when the simulation is carried out using the TRNSYS software, one will obtain energetic consumption for heating and air conditioning.

The following table represents the monthly and annual energy needs for heating and cooling.

Table 1. The monthly and annual energy needs for heating and cooling

(Summary value for all zones)

\begin{tabular}{|c|c|c|}
\hline Months & $\begin{array}{c}\text { Heating } \\
(\mathrm{kWH})\end{array}$ & $\begin{array}{c}\text { Cooling } \\
(\mathrm{kWH})\end{array}$ \\
\hline January & 710 & 19.9 \\
\hline February & 518 & 43.9 \\
\hline March & 463 & 42.4 \\
\hline April & 167 & 79.4 \\
\hline May & 16.8 & 362 \\
\hline June & 114 & 757 \\
\hline July & 0 & 1150 \\
\hline August & 0 & 875 \\
\hline September & 19.9 & 430 \\
\hline October & 8.98 & 410 \\
\hline November & 364 & 70.5 \\
\hline December & 564 & 39.6 \\
\hline Sum & 2810 & 4280 \\
\hline
\end{tabular}

- In the case of passive air conditioning, if the heating and the air conditioning are not in use (the equipment are deactivated in the software options), the temperature 
distribution is obtained for the entire year. This temperature distribution is shown in Figure 3.

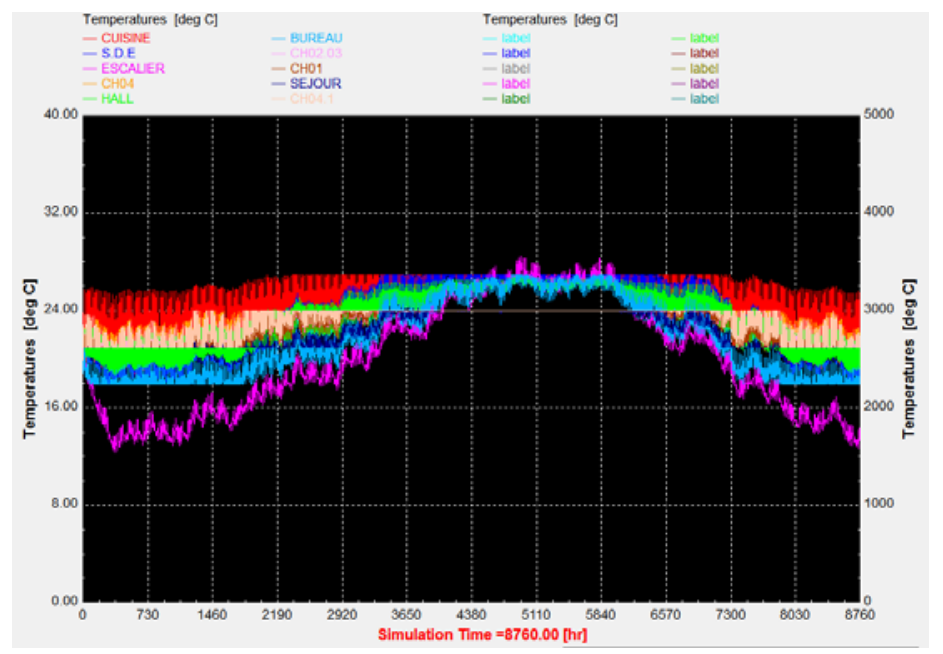

Figure 2. Temperature Distribution in different zones of the building

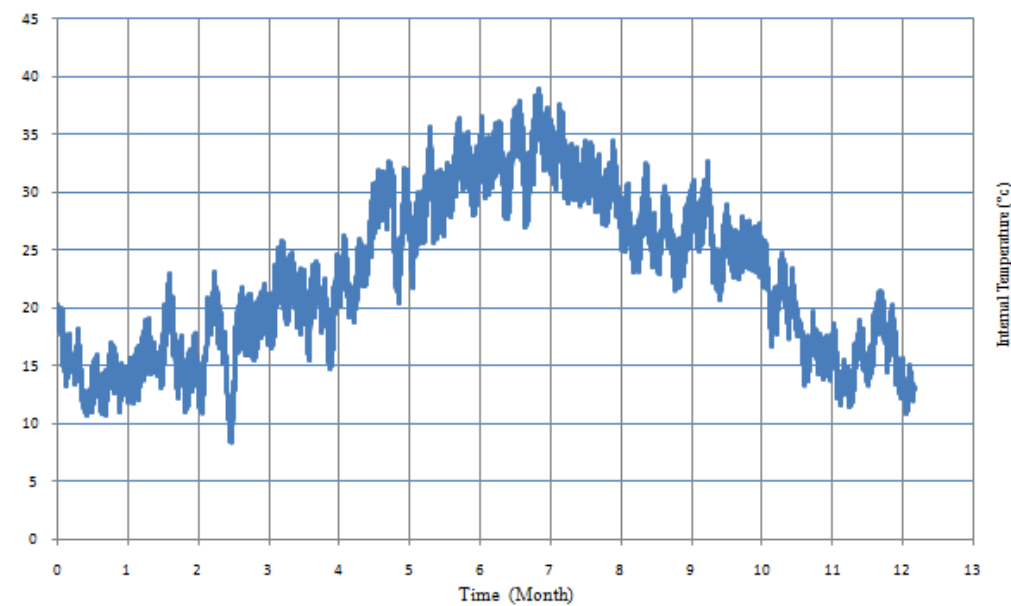

Figure 3. Temperature Distribution in the living room

\section{A statistical analysis of interior temperatures.}

A computer program was implemented in order to process the results obtained by this simulation.

This processing [6] has allowed us to perform a statistical analysis in order to determine the probability density and the cumulative probability of the annual distribution of the interior temperatures in the building.

The following figures represent the probability density and the cumulative probability respectively: 


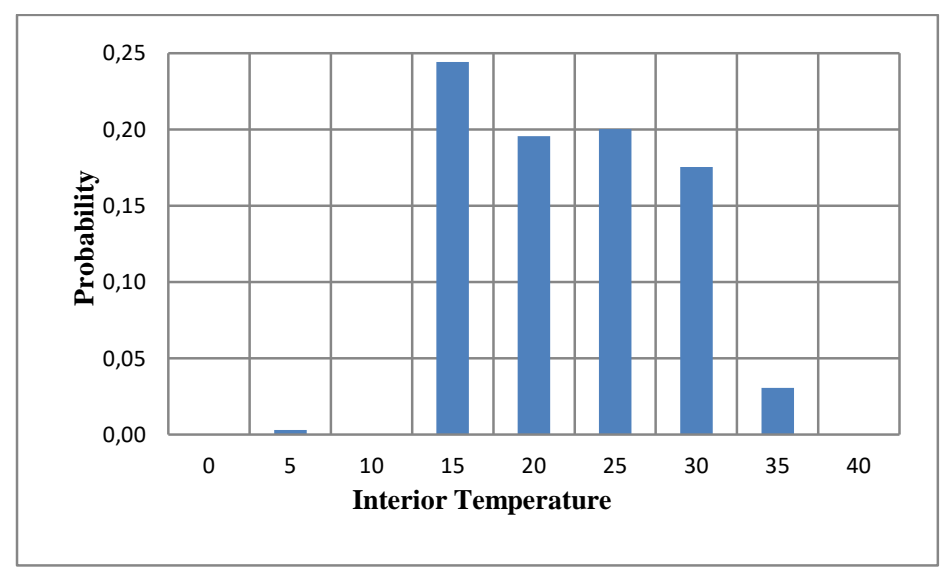

Figure 4. Probability Density of the interior temperature

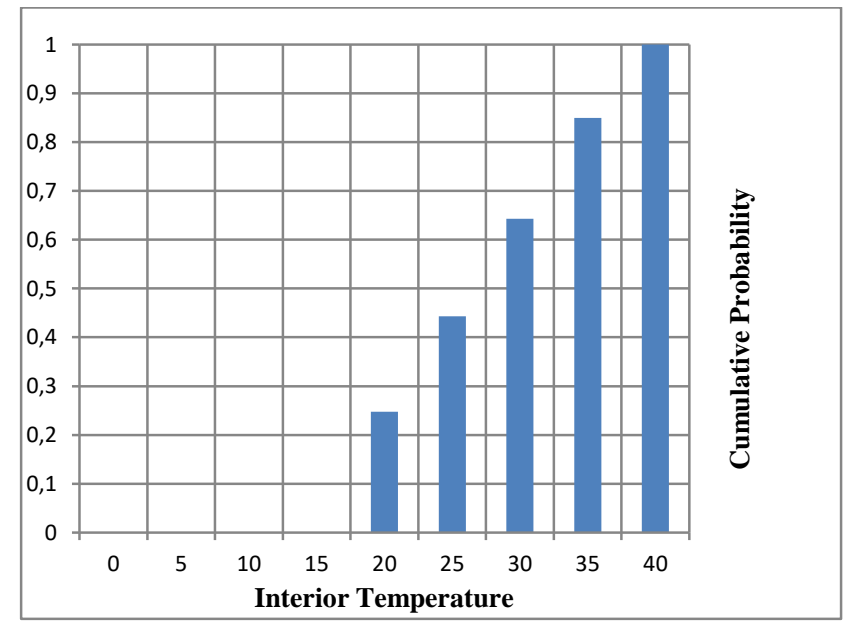

Figure 5. Cumulative Probability of the interior temperature

\section{Estimation of the annual and seasonal durations of comfort inside the building.}

This previous computation has allowed the estimation of the annual and seasonal durations of comfort [6]; these results are shown by the following table:

Table 2. Passive air conditioning, percentage of comfort period

\begin{tabular}{|c|c|}
\hline $\begin{array}{c}\text { Percentage of annual comfort period } \\
\text { (\%) }\end{array}$ & 43,94 \\
\hline $\begin{array}{c}\text { Percentage of Seasonal comfort } \\
\text { period Winter (\%) }\end{array}$ & 14,31 \\
\hline $\begin{array}{c}\text { Percentage of Seasonal comfort } \\
\text { period Spring (\%) }\end{array}$ & 70,97 \\
\hline $\begin{array}{c}\text { Percentage of Seasonal comfort } \\
\text { period summer (\%) }\end{array}$ & 16,08 \\
\hline $\begin{array}{c}\text { Percentage of Seasonal comfort } \\
\text { period Fall (\%) }\end{array}$ & 72,21 \\
\hline
\end{tabular}




\section{Conclusion.}

After the processing of the results of passive air conditioning, using a computer program, one can draw the following conclusions:

- The most frequent interior temperature is $15^{\circ} \mathrm{C}$ with a probability value of 0.24 .

- The season which has the maximum comfort period is the autumn, with a comfort assured during $72.21 \%$ of the time, followed by the spring season with a comfort assured during $70.97 \%$ of the time.

- The season which has the minimum comfort period is the winter, with a comfort assured only during $14.31 \%$ of the time.

\section{References}

[1] Agence Nationale pour la Promotion et la Rationalisation de l'Utilisation de l'Energie (APRUE, Algeria)., "Programme de développement de l'efficacité énergétique à l'horizon 2030”, (2015) : 4-9.

[2] European Investment Bank., "Mécanisme Financier pour le développement de l'Efficacité Énergétique et des Énergies Renouvelables Dans les pays sud- et estMéditerranéens”, Rapport Final (2007) : 151-176.

[3] Boursas, A., "Étude de l'efficacité énergétique d'un bâtiment D'habitation a l'aide d'un logiciel de simulation”, Mémoire de magistère, département de génie climatique, Université de Mentouri Constantine (2013) : 34-41.

[4] Ghedamsi, R., Settou, N., "Modeling and forecasting energy consumption for residential buildings in Algeria using bottom-up approach”, Energy and Buildings 121 (2016) : 374-388.

[5] Missoum, M., Hamidat , A., "Impact of rural housing energy performance improvement on the energy balance in the North-West of Algeria”, Energy and Buildings 85 (2014) : 309-317.

[6] Ftiman, K., Layeb, Z., “Analyse et optimisation des périodes de confort pour une climatisation passive d'un bâtiment et évaluation de ses besoins énergétiques en chauffage et climatisation à l'aide d'un logiciel de simulation”, Mémoire de master, département de génie climatique, Université des frères Mentouri Constantine (2017) : 27-31. 